\title{
Nyepi Holiday Package: \\ Between Commercialization, Commodification and Revolting to Hegemony
}

\section{Nararya Narottama}

Lecturer at The Bali International Tourism Institute

Corresponding author: naro_osh@yahoo.co.id

\section{ARTICLE INFO ABSTRACT}

Received

29 September 2015

Accepted

01 February 2016

Available online

07 March 2016
Nyepi is a sacred and a holy day for Hindus in Bali, Indonesia. It only happens once a year. At Nyepi time, for one day, all day activities in Bali are stopped, and the Hindus shall carry Catur Bratha PeNyepian, which consist of: Amati Karya (not working), Amati Geni (not light a fire), Amati Lelungan (not traveling) and Amati Lelanguan (not having fun/entertainment). Along with the rapid development of tourism in Bali, a Nyepi ritual is also inseparable from the shadow of tourism commercialization. In the last decade, more and more businesses are offering Nyepi holiday packages to tourists. Surely this is contrary to the real essence of Nyepi. The purpose of this research is to reveal what tourism through the commercialization of Nyepi holiday packages which has been done through the commodification of Nyepi as compared to its real meaning and how does Nyepi become a new hegemony in the sphere of social multiculturalism. This research approach is qualitative description, and the theorical used, among others: the commodification theory, the theory of hegemony and the theory of consumerism. The result show that the influence of commercialization and commodification of Balinese culture is an outcome of the advancement of tourism. Nyepi commodification occurs in the process of modernization, which is rooted in capitalism and the increasing of heterogeneity in Bali. This phenomenon appears as an attempt by revolts against prevailing hegemony of Nyepi in Bali.

Keywords: nyepi, holiday package, commercialization, commodification, hegemony, consumerism

\section{Introduction}

The tourism concept developed in Bali cannot be separated from culture and religion, as this is its soul. Through the "Bali Regional Seminar on Cultural Tourism" in 1971, the concept of "Cultural Tourism" formally adapted and used as a slogan to Bali's tourism (Picard, 2006). This was confirmed by the Regional Regulation (Perda) No. 3 of 1974 issued by the Government of Bali, and then updated by Perda No. 3 of 1991 on Cultural Tourism. More than a decade later, this concept is reinforced through the Bali Provincial Regulation No. 2 of 2012 on
Cultural Tourism of Bali. So from the beginning, it has been declared, that the kind of tourism developed in Bali is tourism based on the culture of Bali, which are inspired by the teachings of Hinduism, and a philosophy of Tri Hita Karana. All activities of the majority of the people of Bali are inseparable from Hinduism in its foundation.

As part of the effort to draw closer to God, the Hindu community implemented a series of ceremonies Nyepi in Bali. This is in accordance with the decision of PHDI (Parisadha Hindu Dharma Indonesia - the highest assembly of Hindus in Indonesia), 
Nyepi in Indonesia is a celebration for the Çaka New Year from India. Nyepi ritual includes seclusion, purification, restriction of movement of the body and the mind, introspection and contemplation. It is expected that this be done, in silence and solitude so the Hindus in gain spiritual enlightenment and get closer to God.

The celebration of Nyepi is a day that is sacred to the Hindu community in Bali, when Nyepi starts, during one day, all activities in Bali stop, including the closure of roads, seaports and airports. Lighting, transportation and electronics should not be used. They hope all of the Balinese Hindu community can peacefully implement Catur Bratha Penyepian, which consists of: Amati Karya (not working), Amati Gni (not light a fire), Amati Lelungan (not traveling) and Amati Lelanguan (not having fun/entertainment).

However, Nyepi is also inseparable from the shadow of commercialization and commodification of tourism. In the last decade, more and more tourism businesses are offering Nyepi holiday packages to tourists. Surely this is contrary to the real essence of Nyepi itself. Problems try to convey, among others: what tourism, through the commercialization of Nyepi holiday packages, has done with the commodification of Nyepi as compared to its real meaning? As well, how Nyepi has become a new hegemony in the sphere of social multiculturalism?

This research is important, given that the Hindu religion is the soul of the Balinese culture, and also the roots of Bali's tourism. A culture intact will provide great benefits for the sustainability of Bali's tourism in the future.

\section{Research Objective}

The purpose of this research is to study about commercialization of Nyepi holiday packages which has been done through the commodification of Nyepi compared to its real meaning and how does Nyepi become a new hegemony in the sphere of social multiculturalism.

http://ojs.unud.ac.id/index.php/eot

\section{Literature Review}

As far as the authors' concern, no studies have specifically discussed the commercialization and commodification of Nyepi holiday packages in Bali. However, there are some references in this study, among others: First, the study entitled Identitas dan Komodifikasi Budaya dalam Pariwisata Budaya Bali - Cultural Commodification in Bali Cultural Tourism (Putra, 2008). In this study, he discussed how tourism and the presence of tourists could influence social and cultural life of a nation. The artists' orientations are no longer in religious art, but more on the commercial orientation, and art has experienced commoditization, where the value of art has been measured by money (market value). Second, a study entitled Komodifikasi Budaya Populer dalam Pariwisata - Commodification of Popular Culture in Tourism (Surbakti, 2008). In this study, he emphasized that industrialization led to the commodification of tourism has really happened in Bali, not only by tourism investors, but also by their own local communities. Popular tourism products in postmodernist culture are suspected of being culturally shallow and simply considered a negative impact of tourism.

Both researchers bring the concept of thinking, about the practices of the commodification of popular cultures in Bali. While, this study focuses more on the commodification of Balinese culture through commercialization on Nyepi holiday packages, in addition, this study also discusses 'cultural rebellion' as a result of the hegemony of Nyepi in Bali.

\section{Theoretical Concepts}

Nyepi is the Hindu's feast day to celebrate the Çaka New Year (Tilem Kesanga). Nyepi became known and formally adopted by the public in 1983, and the Ogohogoh (a giant, monsters like puppet as a symbol Bhuta Kala / negative energy, which is then burned in night before Nyepi starts) on the eve of Nyepi is a new phenomenon (Pringle, 2004). As a new tradition, Nyepi has been considered an important day in the Hindu tradition in Bali. Especially, Nyepi is the only Hindu feast that gained legitimacy as a national holiday in Indonesia. 
The main purpose of the celebration of Nyepi is to invoke the presence of God Almighty, to cleanse Bhuana Alit (human nature / microcosmos) and Bhuana Agung (universe / macrocosmos). At the peak of Nyepi ritual, the Hindu people do Catur Brata Penyepian, which consists of: Amati Geni (do not use or turn on the fire, including the use of electricity and turned off the light), Amati Karya (not working), Amati Lelungan (not traveling), Amati Lelanguan (not entertained, by either TV, internet, or radio), as well as be more focused to do meditation, Tapa, Brata, Yoga, and Samadhi (contemplation).

Catur Brata Penyepian lasts for 36 hours starting at 06:00 am in the morning, till 06:00 pm the next day. A series of ceremonies Nyepi, among others: Melasti ceremony doing the cleaning to the sea / river, Tawur (Pecaruan) - offerings ritual, Pengrupukan now dominated by parading Ogoh-ogoh, Nyepi and Ngembak Geni - phase to end Tapa, Bratha, Yoga and Samadhi, then visiting families and relatives, then forgiving one another, as well as praying together with all family members (Suwantana, 2010).

\section{Implementation of Nyepi has a} spiritual power that can strengthen the mental and self-identity of the people. Through the concept of self-control and contemplation (by look inside themselves), Nyepi can reinforce the integration of mankind in the universal sense.

\section{Methodology}

The method used in this research is a descriptive qualitative with the phenomenological approach, in which the researchers tried to explore the meanings and identify the commercialization of Nyepi holiday packages. Data collection techniques used were in-depth interviews with tourism stakeholders and religious figures, literature reviews and documentation.

\section{Results and Discussion}

Bali is an icon of tourism in Indonesia, as it has attracted many tourists, both local and international. Of course, in addition to providing benefits to Bali, tourism also has consequences in the form of negative impacts.

http://ojs.unud.ac.id/index.php/eot
One of them is the commodification of culture. Commodification is a real phenomenon in Bali, especially in the sectors of tourism industry. In Bali, commodifications also arise in the context of spirituality and religion. Bali tourism has forced people to be part of the international multi-cultural society, and unconsciously has brought local communities sandwiched between maintaining traditions and culture (which is a commodity that can be sold), while on the other hand the process of internationalization through tourism means banging the culture with the modern world (Narottama, 2011). In addition, the Balinese are known to be very strict in applying and passing on cultural traditions to the social environment among themselves, but on the other hand, very loose application to foreigners / outsiders.

Since the Balinese people are aware of the role of tourism in improving the economy, the Balinese people no longer seem to restrict tourism to be present in all aspects of their lives, and tourism can easily fit in the realm of customs, traditions, religions and cultures. Balinese society is able to adhere to the tradition and culture among them, and be able to take advantage of the cultural traditions and economic benefits for the purpose of tourism.

Along with the increase in demand in the tourism industry, a small portion of local people in Bali later became an intermediary of culture (cultural broker), and materialism has made the Balinese people consciously modify their cultural products for tourist consumption. Nevertheless, the people of Bali are still able to distinguish the performances for themselves, for their gods, and those especially for tourists, besides that, they know the boundaries between which products are sold to tourists and which should be protected from commercial exploitation (Howe, 2006).

The term commodification began to be well known about this last decade. Commodification commonly is known also by the term of commercialization, capitalization, commoditization, touristification (Ritzer, 1999; Picard, 2006). Commodification is to make something directly and intentionally (with full consciousness) as a commodity. Commodification refers to the symptoms of contemporary economy, and tourism is a 
sample of perfect commodification (Surbakti, 2008). Commodification or touristification is a form that capital owners desire with full awareness and business calculations utilizing cultures with various symbols, icons and religious art and culture as a commodity for markets (Redaksi, 2008).

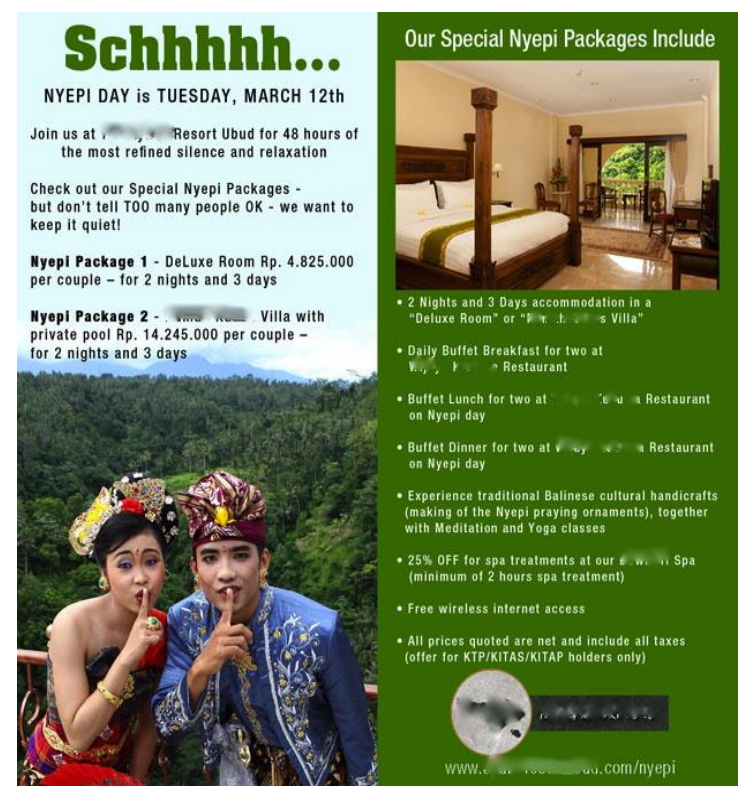

Figure 1. An advertisement that offers Nyepi package at a resort in Ubud.

The picture show how we asked that not to make any voice -the models show by its body language and Schhh ...! - because of Nyepi. There clearly implied how the values of Nyepi has been commodified and commercialized.

According to Barker (2004: 408 in Surbakti, 2008), commodification is the process associated with capitalism in which the object, quality, and a sign are used as commodity and the commodity is something whose sole purpose is to sell in the market. Nyepi ceremony and the entire rituals, was originally not intended for commercial use, but in reality, the ritual has been commodified in such a way to be commercial because of the grip of materialism and capitalism tourism.

Culture, as a tourist attraction in Bali often undergoes a process of compromise for the sake of improvement "selling points" to tourists. Unfortunately, religious values are often packaged together to attract tourists. Initially, a Nyepi holiday package is to accommodate travelers; international,

http://ojs.unud.ac.id/index.php/eot domestic and non-Hindu Balinese people who do not celebrate Nyepi. Over time, more and more tourists are on holiday, who are interested to know the atmosphere of Bali during Nyepi.

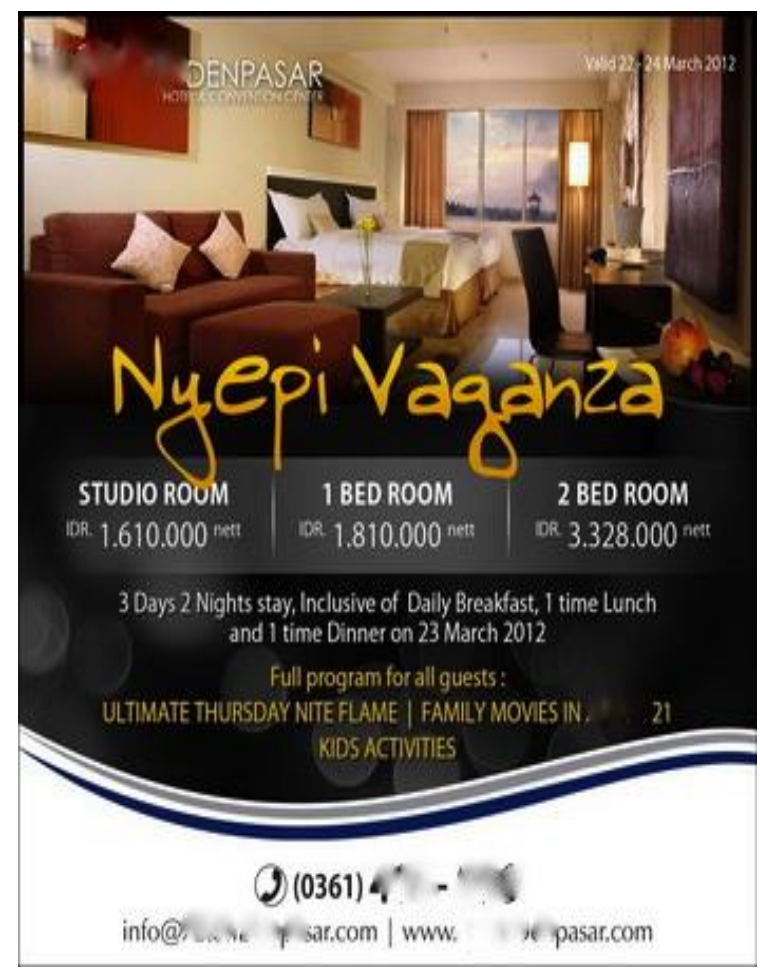

Figure 2: 'Nyepi Vaganza' package in a hotel at Denpasar

The above figure tell us that the word 'Vaganza' means festive, massive. This is really deviate from the essence of Nyepi, like restraint, inward contemplation and simplicity.

In the last decade, the promotion of Nyepi holiday packages are more intense, and it's mostly held in luxury hotels. This is due to the intensity of marketing in various mass media. The packages are promoted through print media (newspapers, magazines, tabloids) and electronic media (internet). The price range offered is quite varied, depending on duration of stay, the programs and the hotel class. Prices range from eight hundred thousand rupiah, up to fourteen million rupiah for two days. Activities offered in the Nyepi holiday package are also diverse, from dining at the restaurant, watching movies / DVD, spa treatments, and also making some Nyepi's ornaments.

The presence of tourists with all the customary habits often creates the effect of

e-ISSN: 2407-392X. p-ISSN: 2541-0857 
"mimic" by the locals. The habit, which imitated, could be good, or even bad, and in a certain period of time, it can shift the values of the local culture (Putra, 2008). The consumer of the package are not only non-Hindu locals, domestic tourists and foreign tourists, but has started to be consumed also by the local Hindu in Bali. Thus, hotel is seems like an escape for those who do not celebrate Nyepi.

When a ritual of Nyepi takes place, there are those (Balinese and non-Balinese, Hindu and non-Hindu) who feel constrained and overburdened. They feel uncomfortable on the various limitations during Nyepi. This discomfort increased with the new rules that prohibit local TV and radio broadcasts during Nyepi day. This inconvenience they shed through social networking sites. They blaspheme and revile the ritual of Nyepi in Bali, one of which is the case of Ibnu Rachel Farhansyah's Facebook status that angered the people of Bali a few years ago.

Although Nyepi is just a day, they feel compelled, hegemony and marginalized. By "escape" to the hotel, they feel freed and satisfied. Nyepi package at the hotel seemed to establish themselves into popular culture in the community. In addition to local and foreign tourists, many customers are new families and derived from the group, which are capable financially. Gramsci (1971) in his book: Selections from the Prison Notebooks uses the term 'hegemony' to refer to the way the dominant group in a society gains support from groups in subordination through the process of "leadership" of intellectuals and morals.

Hegemony is domination by consensus or agreement, directly or indirectly, and openly or secretly which influences the cognitive structures and affective controlled group (Surbakti, 2008). They are in revolt over Nyepi hegemony that has lasted for decades. Instead of doing Tapa, Yoga, Semadhi and self-contemplation for themselves, they prefer to take off and satisfy the senses and rebel rebelled against important symbols of the religious culture of Bali.

http://ojs.unud.ac.id/index.php/eot

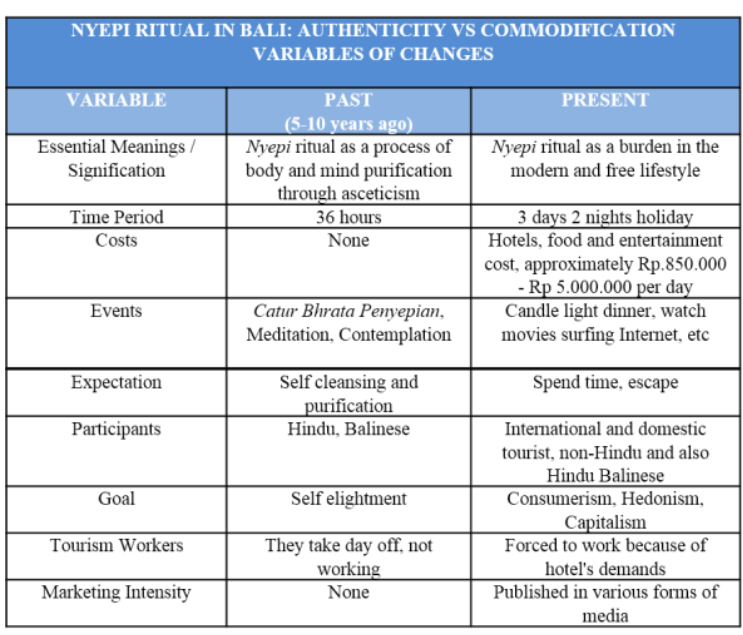

Figure 3. Variables of Change on Nyepi Ritual, Past and Present.

Increasingly widespread marketing of Nyepi packages in a variety of mass media, showed that this tourism product can be received and absorbed by the market. In addition to foreign tourists, the other consumers are the Balinese people who want to release the senses' thirst and want to feel a different sensation from the Nyepi celebration in previous years. Surely this cannot be separated from the modern urban lifestyle that has embraced today's society.

The term 'consumerism' is defined as understanding / lifestyle that considers goods (luxury) as a measure of happiness, pleasure, not frugal lifestyle, etc. Consumerism is a mindset and actions where people buy things not because he/she needs the goods, but because the act of buying itself gives satisfaction to him/her (Soedjatmiko, 2007). Consumption is not only to meet preference and basic human needs, but also deals with symbolic elements to mark class, status, or a particular social symbol. Consumption is also used as a tool to express social differentiation.

To do a Nyepi holiday package at the hotel is no longer a necessity, but it has turned into a form of prestige, to show an increase in a person's socio-economic class. According to Baudrillad, in consumerism, the underlying thought is not the logic of needs, but is shaped by man's desire, which assumes that all needs can be met by consumption (Baudrillard, 1970). Consumerism itself has become a life style of contemporary society. Through advertising and promotion in various media, 
consumption is always present wherever and whenever, even used as a solution when a problem arises. When a person thinks that doing Catur Bratha Penyepian is considered a burden, then by buying a Nyepi holiday package, he/she can eliminate the burden, as well as raise their prestige.

\section{Conclusion}

It is very common in Bali, that art and religious traditions wrapped in culture are commercialized and serve as a major tourist attraction. Along with this, the presence of foreign tourists as well as their culture is considered a threat called 'cultural pollution', and is regarded as a' trigger of degradation' of the Balinese culture.

Unfortunately, Bali has already opened itself to international tourism. This is the reason the people of Bali easily adopt tourism as an important sector for their economy sustainability. In fact, tourism can, and often appears in the realm of religion in society. Thus, Balinese cannot differentiate between its own values with the values brought by foreign tourists. Although at first, Nyepi has nothing to do with tourism and commercial purposes. But in fact, Nyepi holiday packages are sold in hotels. This indicates that Nyepi ritual has commoditized, because it was created with the primary objective to become a commodity for the sake of tourism. Increasingly the widespread marketing of Nyepi holiday packages, prove that the market can accept these commodities. It is feared, authentic Balinese cultural traditions herded into a touristic culture, which is the confusion between cultural values and tourism.

Religious rituals are no longer only for spiritual, but also an economic issue, and it often becomes a commodity. A sacred ritual, for the capitalists, was no longer as something that is upwards to divinity, but it could be, something that makes their merchandise sell, and their revenue increase dramatically. Nyepi commodification occurs in the process of modernization, rooted on capitalism, and the increasing cultural heterogeneity in Bali. On one hand, this phenomenon appears as an attempt by revolts against prevailing hegemony on Nyepi in Bali.

http://ojs.unud.ac.id/index.php/eot

\section{References}

Barker, C. (2004) Cultural Studies, Teori dan Praktik. Yogyakarta: Bentang Budaya.

Baudrillard, J. (1970) La Société dé Consommation. Paris: Danoel.

Gramsci, A. (1971) 'The philosophy of praxis', Selections from the prison notebooks of Antonio Gramsci. Lawrence \& Wishart London.

Howe, L. (2006) The changing world of Bali: religion, society and tourism. Routledge.

Narottama, N. (2011) Pariwisata Budaya dan Komodifikasi, Suatu Pergulatan Kebudayaan. Available at: http://sangikankecil.blogspot.com/201 1/12/pariwisata-budaya-dankomodifikasi. (Accessed: 22 January 2014).

Picard, M. (2006) Bali: pariwisata budaya dan budaya pariwisata. Kepustakaan Populer Gramedia.

Pringle, R. (2004) A short history of Bali: Indonesia's Hindu realm. Allen \& Unwin Australia.

Putra, A. M. (2008) 'Identitas dan Komodifikasi Budaya dalam Pariwisata Budaya Bali', Jurnal Analisis Pariwisata, 8(2), pp. 7-16.

Redaksi (2008) 'Pengantar', Analisis Pariwisata, 8(2).

Ritzer, G. (1999) Enchanting a Disenchanted World, Revolutionizing the Means of Consumption. Thousand Oaks: CA: Pine Forge Press.

Soedjatmiko, H. (2007) Saya berbelanja maka saya ada: ketika konsumsi dan desain menjadi gaya hidup konsumeris. Jalasutra.

Surbakti, A. (2008) 'Komodifikasi Budaya Populer Dalam Pariwisata', Analisis Pariwisata: Komodifikasi budaya Dalam Pariwisata, 8(2).

e-ISSN: 2407-392X. p-ISSN: 2541-0857 
E-Journal of Tourism Vol.3. No.1. (2016): 14-20

Suwantana, G. (2010) Nyepi Tradisi dan

Esensi. Majalah Hindu Raditya.

Available at:

http://www.parisada.org/index.php?op

tion $=$ com_content $\&$ task $=$ view\&id $=16$

70\&Itemid=29 (Accessed: 21 January

2014). 